Flexibility, Compromise and Opportunity:

Students' Perceptions of Balancing Part-Time Work with a Full-Time Business Degree

Evans, C; Gbadamosi, G \& Richardson, M

This is the pre-print version of the paper cited as:

Evans, C., Gbadamosi, G. \& Richardson, M. (2014) "Flexibility, compromise and opportunity: students' perceptions of balancing part-time work with a full-time business degree" International Journal of Management Education, Vol. 12, No. 2, 80-90. DOI: 10.1016/i.ijme.2014.02.001 


\title{
Flexibility, Compromise and Opportunity: \\ Students' Perceptions of Balancing Part-Time Work with a Full-Time Business Degree
}

\begin{abstract}
Amidst the growing importance of employability in higher education, this study explores and identifies the motivations behind full-time university students engaging in part-time employment during term time, how students cope with simultaneously managing the two activities and how part-time working influences their career aspirations. Semi-structured interviews are used to obtain data from a sample of 30 business degree students at a UK university.
\end{abstract}

The findings confirm previous studies, that financial necessity is a primary driver of parttime work, but also reveal a complex set of supplementary reasons, that either satisfies a long-term vision, or a more immediate need for development or self-gratification. Furthermore, most students compromise the longer term benefit of study against the more immediate financial gains offered by work, resulting in an accepted lowering of academic performance as a consequence. The majority of the students did not see a connecting opportunity between their part-time work and future career, and were uncertain regarding future career direction.

This study extends the use of qualitative methods in this area, which is dominated by survey research, while also extending extant findings to the career aspirations of students, which is hitherto largely unexplored. 


\section{Introduction}

The bulk of academic work describing part-time working patterns whilst studying full-time in higher education (HE) have been generated from samples of UK university students. Working part-time whilst studying for a full-time degree is, however, not a UK phenomenon. In particular, Morrison (2009) identifies similarities in patterns and reasons for working among Chinese HE students, to students from other countries. Another longitudinal study conducted by Hall (2010) on Australian HE students concluded with findings that were consistent with previous UK studies. Even though studies in the US have tended to focus on the part-time working activities of High School students (see for example Holloway, 2001), the work of O'Connor and Cordova (2010) provides a useful analysis of graduate school students who concurrently work. Notwithstanding a recognition that patterns of students' working may differ internationally, this paper builds on the existing volume of work regarding students' part-time working in the UK (see for example, Carney et al, 2005; Curtis \& Shani, 2002; Richardson et al, 2009; Watts, 2002).

Since the Leitch Report (2006) recommended that universities encourage more active employer engagement within the curriculum, the contemporary $\mathrm{HE}$ environment has seen an increase in work-related activities being offered to students, such as short-term or oneyear business placements and various forms of work-based project and work-related learning (Knight \& Yorke, 2002, 2003). Yet, at the same time as universities are embedding employability frameworks and activities within their curriculum (Smith et al, 2007), the numbers of students working part-time whilst undertaking a full-time degree has also increased (NUS/HSBC Students Research Report, 2008). While it might be argued that this activity embraces the sectoral strategic shift, other factors, in particular structural changes in industry, where deregulation, expansion, and a move to 24-hour service availability, has increased the need for flexibility of labour, especially part-time and casual staffing (IDS, 2008), providing opportunities for students to earn whilst studying. Perhaps more significantly, the financial hardship of $\mathrm{HE}$ students has been highlighted in recent reports (Endsleigh, 2012; NUS, 2010a; NUS, 2010b), giving rise to the conclusion that part-time work is now a necessity in order to survive financially while at university.

There has been a corresponding increase in academic work in this area. Yet, given the multifaceted research that surrounds part-time working, no single conceptual model exists that embraces the broad spectrum of students working whilst studying at university, despite calls for a theoretical framework (Broadbridge \& Swanson, 2005). Here, studies have predominantly focused on students' part-time work activities, particularly their motives (Richardson et al, 2009), or its impact upon academic performance (Curtis \& Shani, 2002).

\section{The impetus to work part-time whilst studying full-time}

Several studies highlighting the growing number of full-time undergraduate students engaged in some form of paid part-time employment are widely discussed (see for example Neill et al, 2004 and Richardson et al, 2009). The main theme to emerge from these works has centred on the growing need amongst higher education students to work part-time to reduce financial hardship (NUS, 2008), with Targetjobs.co.uk (2008) highlighting the substantial gap between income and the combined costs of tuition fees and living expenses. 
Evidence therefore suggests that full-time students in higher education who work part-time, are often motivated by financial necessity rather than a desire to enhance future employability prospects (Davies, 2000; Neill et al, 2000; Richardson et al, 2009).

Consequently, the apparent motivation for part-time working is an effort to provide additional income and avoid excessive debt, while maintaining a certain standard of living (Moreau \& Leathwood 2006; Richardson et al 2009). Harrison \& Chudry (2011) noted that student indebtedness has coincided with the growth of part-time working, while Carney et al (2005) found that being in debt and working part time have a very slight, albeit significant, detrimental effect on both mental and physical health of students. More significant is their finding that students, who felt that part-time working had affected their academic performance, generally worked more hours.

\section{The effect of part-time work on academic studies}

While part-time work does offer positive non-financial benefits such as the development of personal skills; it limits the amount of time available for academic study (Harrison \& Chudry, 2011). On the positive side, employers indicate that a good profile of part-time employment can help supplement a relatively weak academic profile; as well as provide evidence of enhanced communication and teamwork skills that can be drawn out at interview. The positive and negative implications of engaging in part-time work whilst studying full-time have been well documented (Neill et al, 2004; Watts \& Pickering, 2000). A significant amount of work has focused on the potentially detrimental effects that part-time working has on academic performance, with some studies confirming a converse relationship (Lillydahl, 1990; Salamonson \& Andrew, 2006). Neill et al (2004) argue that working 15 hours per week is the optimum beyond which part-time work may become disadvantageous. Nonetheless, the literature remains inconclusive, and Green and Jacques (2001) found no relationship between part-time work and students' academic performance. In the UK, Ford et al (1995) and Hodgson \& Spours (2001) both accept that individuals will manage the balance of work and study differently, with some managing their time effectively while others struggle to cope with the demands of both.

\section{Non-Financial Benefits of Part-Time Working for Students}

It is also suggested that many students now recognise that part-time work enhances transferable skills such as time management (Holloway, 2001), although the extent to which students recognise the value of the skills they obtain from part-time work to prospective employers is arguable. Nonetheless, Watts and Pickering (2000) for example, reported that students gained increased confidence and important skills such as effective time management which can be useful in application to the academic arena. In addition, Green (2011) confirms that work placement can have a positive impact on degree performance, supporting the work of Adcroft (2009), who found higher levels of extrinsic motivation among those students who had work placement experience.

Additionally, Lillydahl (1990) suggests that work experience helps the transition into future employment because students become accustomed to the habits, values and attitudes that will be expected of them later in their working lives, as well as gaining opportunities to 
assume greater responsibilities. Similarly, Lucas and Lamont (1998) and Raffe et al (1998) discuss the skills and attributes gained during part-time employment, while Mortimer et al (1996) highlight the positive influence of part-time work in providing students with an opportunity to learn useful skills. In addition, Woolmer \& Hill (1990) note the important role part-time work plays in integrating young people into the workforce.

Billett \& Ovens (2007) noted that work experience secured by full-time students provided useful experience of the nature of work, a greater understanding of the workplace and, in some instances, provided a 'conduit' into full-time employment, while Wignall (2007) sees non-financial benefits of part-time working to include the potential for an individual to attain important work-related skills. Moreover, Patton (2001) sees part-time work contributing to the socialisation of students, suggesting that the opportunity to explore the working environment leads to better occupational preferences and career decisions. However, while Billet \& Ovens (2007) found that part-time working facilitates individual reflection upon future career direction, previous studies have not fully examined the extent to which part-time jobs while studying actually drive career aspirations.

\section{Career Directions}

Whilst Borg (1994) acknowledges that an individual's career decisions can be affected by a multitude of factors, not least the influence of families and other individuals (see also Agarwala, 2008 and Singaravalu et al, 2005), she recognises that perceived future financial returns associated with a particular career choice are a critical deciding factor. This conclusion is supported in later work by Itkin (2008), who also recognizes that earnings potential is an important factor in the career choice of graduates, although Sibson (2011) notes the value students attach to the intrinsic attractiveness of the work itself.

In related work, Piotrowski \& Cox (2004) found that business students are drawn specifically towards a business degree because they anticipate that it will naturally lead them towards better job opportunities and the enhanced earnings potential associated with a career in business. Nonetheless, perceptions of preferred employer can change over the period of study (Danziger \& Eden, 2006). However, whilst earnings potential appears to encourage individuals to undertake a business degree in the first place, Itkin (2008) feels that the broad spectrum of occupations covered by 'business' can make any decision regarding potential career direction difficult. This view is supported by Buchanan et al (2007), who suggest that even though a business degree indicates a sense of career orientation, and is sufficiently broad to provide individuals with a wide range of learning, it is only at the postgraduate level that specific career aspirations becomes apparent. Borg (1994) notes the benefits associated with work experience on choice of future career as it gives individuals a more informed basis on which to make decisions surrounding moving from full-time study to fulltime employment. Work experience is also encouraged by Itkin (2008) as it enables individuals to gain the skills that will allow them to achieve their career aspirations.

Alongside this clear consensus in the literature, there are a number of important variables that appear to influence an individual's career decisions. In particular, personality traits (Gunkel et al, 2010) and gender differences (Al Miskry et al, 2009) appear to affect career aspirations, especially occupational choice. Perhaps unsurprisingly, there is also a 
suggestion by Rainey (2006), that career choice is often influenced by levels of debt, which could ultimately be influenced by the level of part-time working undertaken by an individual whilst studying for their degree.

\section{Rationale and Objectives of this study}

A range of methods have been used to investigate this broad area within higher education. Most authors have, however, employed quantitative methods, such as surveys (see, for example Carney et al, 2005; Curtis \& Shani, 2002; Lucas \& Lamont, 1998; Neill et al, 2004; Richardson et al, 2009). In this study, we have adopted a qualitative approach to allow deeper interrogation and opportunities to explore issues as they emerge. Where qualitative methods have previously been adopted, the focus has been on the impact of part-time working on academic performance (see, for example Watts, 2002; Watts \& Pickering, 2000). The present study takes a broader perspective than merely the relationship between work and academic performance, to include the factors that motivate students to undertake a part-time job whilst in full-time education; how students manage the relationship between work and study; and how part-time work has influenced their career aspirations. This relationship requires further and deeper exploration. Specific areas of interest include the links between part-time work and developing career aspirations (Billett \& Ovens 2007; Itkin 2008) and how students simultaneously juggle work and study for best results (Harrison \& Chudry 2011; Holloway 2001).

By using a qualitative approach this study offers a different perspective and provides some originality by extending the previous work of Richardson et al, (2009), which used a quantitative approach, and by also examining how students' working patterns relate to their career aspirations. Richardson et al, (2009) found that the principal motivating factor for the majority of students undertaking part-time work was financial necessity, with a smaller number seeking to gain experience to support their studies. Students' career aspirations appear to have been more heavily influenced by their course than by their chosen part-time work. These aspects are examined in more depth through the qualitative approach adopted in this study.

Specifically the study focuses on three important areas and questions:

(i) The part-time job: what specifically motivates students towards a part-time job whilst in full-time education?

(ii) The job-education conflict: how do students cope with managing these two tasks simultaneously?

(iii) Career aspirations: how has part-time working influenced individual students career aspirations?

\section{Methodology}

\section{Selecting the Research Sample}

The research participants for this study were undergraduate BA (Hons) Business Management students of a post 92 university in the UK, who were engaged in full-time study during 2010/11. This HEI was selected because of the previous quantitative research activity undertaken in this area by the researchers, so it was deemed that students at this 
institution would be more willing to participate in this follow-up academic enquiry. It was also felt that individuals studying business would be more aware of the benefits of engaging in paid part-time work whilst studying full-time as a means to improve the key transferable skills seen as essential to enhance employability and open up a broader range of work opportunities following graduation. It is however arguable whether business students are more or less likely to undertake part-time work compared with students from other academic disciplines.

\section{The Research Process}

Ethical approval was initially sought and granted by the University, as a mandatory requirement for academic research using human participants, such as the present study. $A$ request for participants to be interviewed was thereafter issued via e-mail early in the academic year 2010/11. All 1300 students, across the three years of the BA (Hons) Business Management programme were contacted. To ensure strict ethical compliance no incentive to participate in the study was offered. A total of 39 students made contact with the researchers but only 30 were eventually available for interviews. The 30 positive responses were received from full-time students engaged in part-time paid employment (see Tables 1 and 2 for breakdown of respondents by year, gender, job type and sector).

Table 1: Breakdown of Respondents by Year and Gender

\begin{tabular}{|c|c|c|c|}
\hline Year of Degree & Male & Female & Totals \\
\hline 1 & 6 & 3 & $\mathbf{9 ( 3 0 \% )}$ \\
\hline 2 & 3 & 7 & $\mathbf{1 0 ( 3 3 \% )}$ \\
\hline 3 & 6 & 5 & $\mathbf{1 1 ( 3 7 \% )}$ \\
\hline & $\mathbf{1 5 ( 5 0 \% )}$ & $\mathbf{1 5 ( 5 0 \% )}$ & $\mathbf{3 0 ( 1 0 0 \% )}$ \\
\hline
\end{tabular}

Three of the respondents (10\%) were mature entry (aged $21+$ ).

Table 2: Breakdown of Respondents by Job Type and Sector

\begin{tabular}{|l|l|c|}
\hline Sector & Job Type(s) (numbers in brackets) & $\begin{array}{l}\text { No. } \\
\text { Students }\end{array}$ \\
\hline Hospitality & Waiting staff (5), Bar staff (1), Cook (2) & 8 \\
\hline Retail & $\begin{array}{l}\text { Sales Assistant (11), Team Leader (1), Assistant Manager } \\
(1)\end{array}$ & 13 \\
\hline Administrative & Call-centre (2), Secretary (1), Administrator (1) & 5 \\
\hline Public Sector & Educator (1), Care worker (1) & 2 \\
\hline Other & Other & 2 \\
\hline & & $\mathbf{3 0}$ \\
\hline
\end{tabular}

Note: The jobs/sectoral profile of the interviewees reconciles to the typical positions secured by full-time degree students (see for example http://www.thestudentroom.co.uk/wiki/Part-Time Work)

Since the purpose of this study was to go beyond the responses associated with a quantitative based survey and explore in more depth the perceptions and motivations of students, it was felt that each individual would make a useful contribution, and so a more scientific and rigorous method of selecting participants was deemed unnecessary. The 
interview was completely anonymous and respondents were informed they could withdraw at any point if they did not want to proceed. The actual interviews were conducted by one of the researchers to ensure a consistent and reliable approach in the process.

Semi-structured interviews were held by only one of the researchers with each of the students in a location within the university. The interview was based around 16 questions, split into three sections: questions about the individual's part-time job, questions exploring the relationship between part-time work and the student's full-time educational experience, and questions relating to future career aspirations (see appendix A). However, students were encouraged to talk freely about their part-time job and their studies, with questions being used primarily as researcher prompts. The interviews were not recorded as it was thought that this might have inhibited discussion. Instead, shorthand notes were taken. The responses were word-processed and participants were requested to confirm them to ensure correct representation of their views. Only one of the authors conducted the interviews to minimise discrepancies and enhance the reliability and validity of data. The interviews were subsequently written-up, and commonality within the responses noted. The commonality was then examined across the questions to derive the themes.

Previous studies in this area have not examined gender differences (for example Payne, 2003, Patton \& Smith, 2010). Where, gender has been considered in part-time working activities (for example, Booth \& van Ours, 2007; Webber \& Williams, 2008), it has largely focused on the difficulties of balancing part-time work with personal and family commitments, rather than students' part-time work being part of an HE scenario. Moreover, given the small-scale research undertaken here, it was felt that to explore patterns of responses within age, gender, module options, ethnicity etc. could have potentially led to some spurious assumptions. The interviewees were therefore treated homogeneously. Six themes emerged from the analysis: notably the drivers to work part-time and the resultant need for flexibility, the potential to impact on choice of career direction, the potential to gain real-life insights, the risk of compromising studies and the opportunities offered to support further development. The findings are presented within these themes.

\section{Findings}

\section{The drivers to work part-time}

The majority (93\%) of respondents stated financial reasons as the main motivator to undertake part-time work. However, the impetus underpinning that motivation highlights two categories of driving force: firstly, the desire to reduce or avoid debt and secondly the desire to maintain a lifestyle that students had become accustomed to prior to entering University.

For students in the first group, the spectre of tuition fees provides a clear focus for taking on paid employment,

"To get as much income as possible to counter tuition fees" (Year 3 Female). 
Rather than take a long-term perspective towards tuition fees, a more immediate fiduciary view is being taken, with the income from the job used simply to help offset the burden of debt in the short-term,

"To make it more comfortable for me to have a reduced debt" (Year 1 Female)

For the second group of students, the standard of living grown accustomed to prior to entering University was seemingly difficult to relinquish once on the degree. Prior to attending University, students were typically living at the parental home, with fewer financial responsibilities and relatively high disposable income. At this stage, driving lessons and purchasing cars are high on the agenda, rather than worries surrounding the burden of covering tuition fees and living expenses. For example, while at school, one respondent stated that he had worked at a cash \& carry store which brought in money to pay for branded clothes and a good lifestyle. After starting University, he found he still needed to work to maintain that lifestyle:

"I got into that lifestyle because I could afford it. When I went to University, I had to continue funding it" (Year 3 Male).

There is seemingly no desire to tolerate an austere lifestyle even in the relatively short-term whilst studying at University and a part-time job thus allows an acceptable standard of living to be maintained.

"My part-time job is crucial to my lifestyle. I try very hard not to spend my student loan as I'm going to pay it back at some point. My part-time job pay has to spread to cover everything I need, from uni books to my social life" (Year 3 Female).

Nonetheless, the financial rewards in themselves are not always sufficient motivators. Two of the interviewees, both working in cafés as waitresses, had turned down promotion opportunities and more pay since it would have entailed longer hours and increased responsibility. Here, the benefits of increased financial reward were countered by the increased burden of job responsibilities, which was deemed by both students to have restricted flexibility and interfered too much with their degree studies.

Whilst financial reasons were stated by most interviewees as a main reason for part-time working, a more fundamental need to demonstrate personal drive and fulfil selfmotivational desires that transcend the financial imperative emerged during the interviews:

"I wouldn't class myself as lazy and so l'd rather work than stay at home and do nothing" (Year 1 Male).

Additionally, one female first year student said that she'd worked since the age of fifteen and she would feel ashamed if she did not have a job. There was a feeling among 14 of the interviewees that they strived to excel in their respective jobs regardless of enjoyment levels. This is surprising since it might be assumed that as they were only working part-time, with aspirations of greater endeavours once the degree has been completed, most students would be relatively unmotivated and adopt a 'couldn't care less' attitude. Yet one student 
stated her pride in her job despite not liking it especially, noting in particular that her sickness and absenteeism level is low, which she attributes to her own self esteem and a sense of pride in her work. Similarly, one interviewee, currently working in retail, receives an appraisal every month and this inspires him to achieve more in the store. He said

"I would like to think that I excel in the job. If a job needs doing, the manager always asks me. I do value the job" (Year 1 Male).

This finding has positive implications for employers, who might otherwise be deterred from employing students on a part-time basis for fear of lack of commitment or potential negative impact on customers.

\section{The Need for Flexibility}

The choice of job that attracts students is seemingly made according to the flexibility provided by the role, rather than level of remuneration. This is deemed essential if students are to balance the competing demands of work and study. Employers clearly demonstrate understanding and flexibility regarding staff timetables, with four interviewees highlighting that they took their University schedule in to work to negotiate working hours rather than having set times forced upon them. For example, one interviewee has classes in the afternoon or evening, and therefore works every morning shift. In addition, three students condense their working hours into the weekend in order to avoid conflict with classes. It is therefore important that employers who wish to employ students to fulfil part-time or temporary posts emphasise flexibility of working above other job attributes, in order to attract such candidates.

Yet, it is clear that flexibility is not always facilitated through negotiation, it is sometimes a forced situation. For example, one interviewee came to an arrangement with his employer to allow attendance at university despite being in a full-time job. As a consequence, he remains permanently logged in to his PC and deals with work e-mails during classes. Nonetheless, there is a two-way benefit of flexible working, with employers gaining a flexible resource, at least for the period that the student is engaged in full-time study. One first year male student acknowledges that while his company does put people first, and that they are flexible to his needs, he feels that this ties him to the company for the duration of his time as a full-time student, as he felt that he would not get such good deal elsewhere.

Although, it does seem that being able to switch-off at work, even though it might be a mundane activity, counters the pressures of studying for a degree,

"It gets boring sometimes, but I wouldn't want to leave as it is so easy" (Year 2 Female).

\section{Impact on Career Direction}

Given that the reasons for working are predominantly financially driven and that employers are sought on the basis of flexibility, it would be reasonable to assume that students would have no desire to continue working for their respective company post-graduation. Yet two of the students intended to utilize the part-time work experience to develop a career with either their current employer, or an organisation in the same sector, following graduation. Moreover, one third year student started work at a large retailer initially as a source of 
income, but then quickly realized that there was potential to develop a career there and now the financial reward seems secondary to carving out a long-term career within that organization. These interviewees recognised the importance of getting in at 'grass-roots' level within an organisation and using that experience to provide a foundation to develop a management career. Given the current difficult jobs market, especially for graduate entrants, it is surprising that more individuals do not look to develop careers with their parttime employer, since many have graduate or management schemes in place.

Nonetheless, with the exception of one student who had aspirations of being a pilot, and another who wanted to pursue retail management with his current employer, for most of the remaining participants (93\%), there was uncertainty regarding future career direction. For those in years one and two of the degree, there was no sense of urgency in directing efforts towards finding a full-time job after graduation. One first year student felt that she needs to concentrate on her degree studies for the immediate future rather than look to the future. Yet, even for those students in year three, with the end of the degree looming, there was still indecision, with one third year student commenting that she had not yet started looking for jobs and did not have any idea of what she wanted to do. Similarly, another third year student stated that she did not have any precise career direction in mind at the moment, and was "just trying to find out what I'm interested in next". One second year student said she would probably do a Masters degree to give her more time to think about future job options.

This indecision could be a symptom of the business degree, which is generalist in its curriculum content and can lead to disparate career pathways. However, this indecision does represent a worrying feature for Universities (since they are measured on graduate employability) and could lead to students continuing for a period in their current part-time post following graduation, and thus delaying their securing a graduate level position. There was an emerging feeling among seven of the interviewees of a 'back-up option' with the current part-time job, and that if a full-time position in an area of interest did not materialize, then individuals would simply remain with their existing part-time employer and try to make the best of the situation. With $40 \%$ of the interviewees already working in excess of 20 hours per week, it seems relatively easy to merely increase hours in an already familiar working environment. One first year interviewee stated that while he does not favour a career in retail, being aware of the difficult economic times, he needs to keep his options open and does not rule it out. Yet, it is suggested here, that this 'back up option' can lead to complacency, since without the sense of security derived from the part-time job, students would potentially be more vigorous in their graduate job search, and also seek opportunities earlier in their studies. This situation could also be compounded by employment inertia, with one interviewee stating that she is the longest serving employee in her department, and accepts that

"I wouldn't say I enjoy it, but it's what I'm used to" (Year 2 Female).

Despite the reluctance of students to convert their part-time job into a full-time career upon graduation, there was agreement among all of the interviewees that work activities had added-value to their respective CV's, with one interviewee commenting that 
"without a job it would be a boring CV" (Year 1 Female).

For nineteen of the participants, it was felt that part-time work experience would help to differentiate them in the graduate jobs market. In particular, there was a perception that skills developed in the part-time job would be readily transferable to other environments. This was a view especially held by those individuals currently working in a customer-facing service position such as retail or hospitality. Yet without knowing which career pathway to take, the thought that part-time work added value to that career seems somewhat naïve. For example, much of the training received to support part-time roles is likely to relate to organisation specific skills such as checkout operations, or basic legislative instruction such as health and safety, rather than the skills that will help to form and enhance managerial career aspirations

Nonetheless, the notion that working part-time provides a taste of what life will be like following graduation was a theme that emerged strongly. Six of the participants felt that those who do not work whilst at University are somehow missing out on a wider life experience. One student notes that she can see some fellow students who live at home, with everything paid for, lacking work and life experience, stating that

"work can give a wider perspective" and that "for people who have never worked or had to be self-responsible, work is an abstract idea at the moment" (Year 2 Female).

She felt that having worked before commencing the degree, and carrying on afterwards, gives her practical "real-life experience". Similarly, she felt that work has made her more self-confident and raised her ability to solve life's problems. This seems to be where the value of part-time work can most dramatically benefit an individual's development - not simply providing a competency to highlight on a CV, but helping individual's to develop softer skills and an innate ability to be more reliant and confident in different situations.

\section{Real-Life Insights}

In addition to work developing softer skills, all of the interviewees had made a connection between the theoretical aspects of their business degree and their practical work environment. One interviewee felt that work gave a more realistic perspective to her studies, and this was confirmed by another who stated

"text books are not always like it is in real life" (Year 3 Male).

Moreover, one student noted that he is now seeing aspects of his marketing studies manifesting themselves in issues addressed at work,

"I could understand the terminology they were using and didn't need to ask questions like some" (Year 1 Male).

Another recognized that his studies reflected his experience in the workplace and can now see crucial managerial aspects, such as the motivation of staff, as important: 
"I find myself thinking about what we've covered at university - but it is not really my position to challenge the manager" (Year 1 Male).

However, the utilization of the students' knowledge was not universally overlooked, with one of the interviewees' academic knowledge being frequently used by her manager - for example being asked her advice on in-store merchandising. Similarly, a third year interviewee stated that he regularly finds things wrong in his work environment based on his theoretical knowledge which provides impetus to improve aspects of work.

Given that students are demonstrating an ability to apply wider theoretical perspectives in the workplace, while at the same time gathering employer-relevant skills, it could be assumed that employers would actively pursue these individuals to join management development schemes, or equivalent, post-graduation. Yet, there seems to be a lack of drive on behalf of employers to retain graduates within their organization, and convince them to develop a career in that organisation, sector or specialisation. One first year student, working in retail, noted that his employer does have a graduate scheme, but he felt it was not pushed, and he only found out about it by accident in the company magazine. He felt that there was an expectation that graduates currently working part-time in the store would leave the organization having graduated (taking valuable 'shop floor' experience with them) and were therefore not worth pursuing. He also felt the position was exacerbated by store managers who do not really care about developing graduates, since they are frequently moved from store-to-store and therefore view staff solely as resources to use during the period while they are based at that particular store.

Failure to encourage undergraduates currently working part-time to consider remaining and developing a career within the organisation represents a wasted opportunity for the employing organisation. A graduate with organisational experience should already have internal knowledge about operations and therefore require a reduced induction period and settle in to role more quickly.

Nonetheless, with the aforementioned career uncertainty among students, there are perhaps failings on both sides to actively pursue what seems like a good opportunity. However, from the interviews, it seems that students are having difficulty balancing the different aspects of their lives, with the consequence that they only take a short-term perspective, negotiating the conflicting demands of work and study, rather than taking a longer-term, career oriented view - in other words adopting an operational rather than strategic perspective. By students taking a more strategic view, the part-time work experience could be used to develop a career path with the organisation that would be mutually beneficial to both parties. This does, however, depend upon employers supporting this viewpoint, rather than seeing part-time students merely as a transient resource.

\section{Compromising Study}

Students find balancing pressures to work longer hours, meet University assessment deadlines and achieve good grades, whilst maintaining a rich social life, problematic. Half of the interviewees experienced difficulties in managing work and study, with the resultant reduction in self-study time, 
"background reading time is reduced" (Year 1 Female).

Similarly, another interviewee stated that because of work commitments it has not been possible to do any extra reading over the degree at all and indeed has

"not picked up a book in 3 years" (Year 3 Female).

For those working in a retail environment, this lack of personal study opportunity tends to be exasperated around assignment times, which typically correspond to busy sales periods, such as the pre-Christmas period and the January sales, when increased working hours are expected by employers. Moreover, those in the leisure or hospitality industry typically work late shifts, and for three of the interviewees this meant they were too tired to study at the end of a shift. For other interviewees, work dominates their lives to the detriment of their studies, with one commenting that

"it feels like you don't stop seven days a week" (year 3 Female).

It is evident that as a direct result of the time pressures created by part-time working students have difficulty balancing the two activities, with a typical compromise being made:

"I leave assignments to the last possible moment" (Year 3 Female).

Unsurprisingly, four of the eleven third year students felt that they would have achieved a better degree classification if they had not worked during term time, as this reduced the time that they could devote to their studies. However, this does have significant implications for Universities who seek to maximise achievement levels for their students. Initiatives being instigated by Universities to maximise student achievement rates will be undermined by students' who seek to compromise in all facets of their life rather than look to maximise study achievements. Again, this suggests a short-term perspective is being adopted by students.

\section{Opportunities for development}

The need for personal development emerged during the interviews, especially in respect of developing more advanced English language skills. It seems that interacting with fellow students on the degree programme provided insufficient communication practice for three of the students, with one stating

"I don't have to work. However, I work to develop skills of communication" (Year 1 Female).

Additionally, one student stated that that working gave her "something to do" when not at university. Similarly, another student recognised that a key benefit of his bar job was that it yields an opportunity to meet people and socialise. Similarly, another student recognised that a benefit of working in a pub was the networking opportunities that can occur from getting to know the regular clientele, and thus build up a portfolio of potential work contacts. Consequently, it does suggest that the university is potentially missing an opportunity to fulfil the personal development needs of students, such as the development 
of highly professional communication skills and greater comfort with networking, which students look to the part-time job to provide.

\section{Conclusion}

It is clear that there is a financial necessity amongst many undergraduate business students that stimulates them to work part-time while studying full-time. Whether the motivation is to fund the lifestyle grown accustomed to prior to University, or to counter the rising cost of tuition fees plus living expenses, it is the monetary driver that provides the primary impetus to seek part-time employment, which broadly supports the findings reported in extant literature (Richardson et al, 2009). Yet beneath this financial motivation, lies a complex set of supplementary reasons that satisfies a more immediate need for development or selfgratification (Billet \& Ovens 2007; Curtis \& Shani, 2002; Davies, 2000; Lucas \& Lamont 1998).

There are apparent tensions between work and study, with some individuals having to continuously juggle their time. While Yum et al (2005) discussed several coping mechanisms for part-time students juggling their work, family and social life, some students are clearly more susceptible to persuasion from managers asking them to work overtime than others, with some making individual judgments based upon the importance of a particular class and its impact on their overall studies. With several students admitting that their grades are lower because of part-time work commitments, there is an apparent compromise being made which sacrifices the longer term benefits of study against the more immediate financial gain offered through part-time work. Previous studies, such as Neill et al (2004), have reported the significant association between student working patterns and their academic performance. Nonetheless, some individuals do ignore the excessive demands of their employer and project into the future, anticipating a financially rewarding full-time job.

Whilst this research has not sought the opinions of HE Institutions, the findings nonetheless raise implications for them. In particular, the lack of commitment of students to fully engage in academic studies in order to accommodate part-time work suggests the need for more robust methods of utilising guided learning hours or more demanding assessments by tutors. However, this could have an adverse impact on achievement levels and, in the longer term, on recruitment. Perhaps a solution is to embrace students' part-time working activities and embed them within the curriculum? Certainly QAA benchmark statements for business and management (http://www.qaa.ac.uk) highlight the importance of integrating theory with practice, and certainly there is now some work being developed in this area (Ogilvie \& Shaw, 2011) which could transform how management education is delivered in the future.

More specifically, the need for flexibility emerged strongly through the interviews, with students seeking part-time employment that fitted around their studies. Nonetheless, it became clear that students regularly experience tensions between the demands of work and study. HEl's may wish to configure their curriculum around students' part-time working and provide a more bespoke offer. There is also a suggestion from the findings, that the onus should be on HEls to provide connections with those organisations who recruit graduates, perhaps through work-based projects, to help ease students' transition into full- 
time graduate employment, perhaps supporting an academic-industry partnership, as advocated by Naude et al, (2009). However, employers often complain that graduates are not 'job-ready', and therefore the case for a greater involvement in the developmental process of graduate skills through part-time working would potentially benefit all stakeholders.

Whilst there is a feeling of contentment that part-time work is contributing in some way to an individual's CV, its precise utility in terms of career outcomes eludes most business students. There seems to be an inability to harness and internalise the key components of part-time work and use them to project forward into a defined career pathway. Here, most are waiting to see what develops post graduation when they plunge into the full-time jobs market. For some, the part-time job is kept as a fall-back position, in case a full-time job does not materialize. This 'just-in-case' approach could well hold students back from committing to a particular career pathway, or precise occupation, and as a result students risk failing to secure good positions early in their careers. Perhaps this pattern is more strongly connected to students of business degrees, since the nature of business and management is disparate and largely context based, unlike say teaching or nursing, and therefore creates uncertainty over future career direction. This could also be exacerbated by inertia in leaving part-time jobs that could well extend into the period following graduation. However, it is surprising that the perception amongst students is that employers do little to encourage them to remain in the organization and develop a career following graduation. One individual working in a retail store, felt that promotion was only available to those who worked 30 or more hours per week, since this was the gauge against which management assess those who are committed to a career within the organization. There is an apparent acceptance among employers of the transient nature of students, and an expectation that they will leave to pursue career aspirations elsewhere. Any thoughts of remaining in the organization to either develop the part-time post, or pursue a graduate management position appear to be entirely initiated by the individual.

Nonetheless, students are generally developing useful skills such as customer service skills whilst in part-time employment, and also affirming personal characteristics of selfmotivation, which should be of utmost importance to potential employers. Future research into why employers do not seem to take full advantage of nurturing the valuable skills already acquired in-house and on-the-job by students would therefore be useful.

\section{Future Research}

This research has revealed some interesting findings regarding students' perceptions about their part-time working, their degree studies and their future career direction. However there are limitations to the work, in particular the students are treated homogenously, with no distinction between ethnicity, gender, age or current circumstances, all of which may potentially influence career decisions. In addition, the focus of this study limits the application of the findings across countries, although its value to similar economies must be considered. Moreover, the use of BA (Hons) Business Management students, albeit across the three years of a degree, ignores the experiences of those of other academic disciplines, and indeed, other institutions, and this could be important, especially for those studying in relatively expensive locations, such as at universities in London. 
While this work extends existing work in this area, and goes some way towards integrating facets that have been previously explored, there is a clear need for an empirical model that will embrace all aspects of students working whilst studying. The inter-connections between the themes identified in this work are clearly inter-related, for example, working a larger number of hours reduces the financial burden but decreases time available to study, which potentially comprises performance and overall award. Within this work, a hierarchical model has begun to emerge, with financial considerations at the apex, and a host of supplementary reasons such as career progression underneath. Nonetheless, an integrative model would need to be derived from a larger sample, than the small-scale research undertaken in this work to overcome the limitations previously noted. 


\section{References}

Adcroft, A. (2009). The motivations to study of undergraduate students in management: The impact of degree programme and level of study. International Journal of Management Education, 9(1), 11-20.

Agarwala, T. (2008). Factors influencing career choice of management students in India. Career Development International, 13(4), 362-376.

AlMiskry, A.S., Bakar, A.R. \& Mohamed, O. (2009). Gender differences and career interest among undergraduates: Implications for career choices. European Journal of Scientific Research, 26(3), 465-469.

Billet, S. \& Ovens. C. (2007). Learning about work, working life and post-school options: guiding students reflections on paid part-time work. Journal of Education and Work, 20(2), 75-90.

Booth, A.L. \& van Ours, J.C. (2007). Hours of work and gender identity: does part-time work make the family happier? Economica, 76, 179-196.

Broadbridge, A. \& Swanson, V. (2005). Earning and learning: how term-time employment impacts on students' adjustment to university life. Journal of Education and Work, 18(2), 235-249.

Borg, R. (1994). Factors determining career choice. Education: The Journal of the Faculty of Education, University of Malta, 5(2), 30-36.

Buchanan, F.R., Kim, K.H. \& Basham, R. (2007). Career orientations of business master's students as compared to social work students. Career Development International, 12(3), 282-303.

Carney, C., McNeish, S. \& McColl, J. (2005). The impact of part time employment on students' health and academic performance: a Scottish perspective. Journal of Further and Higher Education, 29(4), 307-319.

Curtis, S. \& Shani, N. (2002). The effect of taking paid employment during term-time on students' academic studies. Journal of Further and Higher Education,26(2), 129-138.

Danziger, N. \& Eden, Y. (2006). Student career aspirations and perceptions: the case of Israeli accountancy students. Accounting Education: an international journal, 15(2), 113-134

Davies, L. (2000). Why kick the "L" out of "Learning"? The development of students' employability skills through part-time working. Education + Training, 42(8), 436-444.

Endsleigh (2012). Half of students work to help und their studies, http://www.endsleigh.co.uk/Media/Pages/half-of-students-work-to-help-fund-theirstudies.aspx 
Fazackerley, A. (2004). Survey: University life is a far cry from stereotype. Times Higher Education Supplement, April 23.

Ford, J., Bosworth, D. \& Wilson, R. (1995). Part-time work and full-time higher education. Studies in Higher Education, 20(2), 187-202.

Green, G., \& Jacques, S.N. (1987). The effect of part-time employment on academic achievement. Journal of Educational Research, 80(6), 325-329.

Green, J. P. (2011). The impact of a work placement or internship on final year performance: An empirical study. International Journal of Management Education, 9(2), 49-57.

Gunkel, M., Schaegel, C. Langella, I.M. \& Peluchette, J.V. (2010). Personality and career decisiveness: An international empirical comparison of business students' career planning. Personnel Review, 39(4), 503-524.

Hall, R. (2010). The work-study relationship: experiences of full-time university students undertaking part-time employment. Journal of Education and Work, 23(5), 439-449

Harrison, N. \& Chudry, F. (2011). Overactive, overwrought or overdrawn? The role of personality in undergraduate financial knowledge, decision-making and debt. Journal of Further and Higher Education, 35(2), 149-182.

Hodgson, A. \& Spours, K. (2001). Part-time work and full-time education in the UK: The emergence of a curriculum and policy issue. Journal of Education and Work, 14(3), 373-88.

Holloway, J.H. (2001). Part-time work and student achievement. Alexandria, VA: Association for Supervision and Curriculum Development.

IDS (Incomes Data Services). (2008). Part-time workers.

http://www.incomesdata.co.uk/studies/parttime.htm (accessed April 3, 2008).

Innis, K. \& Shaw, M. (1997). How do students spend their time? Quality Assurance in Education, 5(2), 85-89.

Itkin, D. (2008). Career beginnings for business majors. Occupational Outlook Quarterly, Winter, 24-33.

Knight, P.T. \& Yorke, M. (2002). Employability through the curriculum. Tertiary Education and Management, 8(4), 261-276.

Knight, P.T. \& Yorke, M. (2003). Employability and good learning in higher education. Teaching in Higher Education, 8(1), 4-16.

Leitch Report (2006). Prosperity for all in the global economy: World class skills. http://www.hm-treasury.gov.uk/independent reviews/leitch review (accessed 23/2/2009) 
Lillydahl, J.H. (1990), Academic achievement and part-time employment of high school students. Journal of Economic Education, 21(2), 307-316.

Lucas, R. \& Lamont, N. (1998). Combining work and study: an empirical study of full-time students in school, college and university. Journal of Education and Work, 11, 41-56.

Moreau, M-P. \& Leathwood, C. (2006). Balancing paid work and studies: working (-class) students in higher education. Studies in Higher Education, 31(4), 23-42.

Morrison, K. (2009). Higher education students in part-time work in a Chinese city. Evaluation \& Research in Education, 22(2-4), 121-144.

Mortimer, J. T., Pimentel, E.E. Ryu, S. Nash, K. \& Lee, C. (1996). Part-time work and occupational value formation in adolescence. Social Forces, 74(4), 1405 -1418.

Naude, M., Novak, M., Thomas, G. \& Rowe, A.L. (2009). Managing Industry-academia partnerships. International Journal of Management Education, 8(3), 71-82.

Neill, N., Mulholland, G. Ross, V. \& Leckey, J. (2004). The Influence of part-time work on student placement. Journal of Further and Higher Education, 28(2), 123-137.

NUS (2009). Overstretched and overdrawn: Student Hardship Survey: available at website. http://www.nus.org.uk/Documents/Overstretched\%20and\%200verdrawn.pdf

NUS/ HSBC Students Research Report (2008). National Union of Students survey: available at website. http://www.nus.org.uk/en/News/News/Credit-crunch-set-to-hit-degree-marks-/ http://nases.org.uk/files/hsbc\%20nus\%20employability\%20report.pdf Accessed April 20, 2011

NUS/HSBC Students Experience Report: Finance and Debts (2010a).

http://www.nus.org.uk/PageFiles/12238/NUS-HSBC-report-Finance-web.pdf

Accessed April 20, 2011

NUS/ HSBC Students Experience Report (2010b). Students in employment \& Post Course Plans. http://nases.org.uk/files/hsbc\%20nus\%20employability\%20report.pdf Accessed April 20, 2011

O' Connor, B.N. \& Cordova, R. (2010). Learning: the experiences of adults who work full-time while attending graduate school part-time. Journal of Education for Business, 85, 359-368.

Ogilvie, C. \& Shaw, S. (2011). Using Student Part-time Work as a Site for Structured Creditrated Undergraduate Work-based Learning. Higher Education Academy. [Online]. Available from:

http://www.heacademy.ac.uk/assets/bmaf/documents/publications/Case_studies/enhanci ng-graduate-impact/Ogilvie_Shaw.pdf 
Patton, W. (2001). Career education: what we know. What we need to know. Sydney Enterprise, Career and Employment Foundation.

Patton, W. \& Smith, E. (2010). Part-time work of high school students: impact on employability, employment outcomes, and career development. Australian Journal of Career Development, 19(1), 54-62.

Piotrowski, C. \& Cox, J.L. (2004). Educational and career aspirations: views of business school students. Education, 124(4), 713-716.

Payne, J. (2003). The impact of part-time jobs in years 12 and 13 on qualification achievement. British Educational Research Journal, 29(4), 599-611.

Raffe, D., Biggart, A. Fairgreive, J. \& Howieson, C. (1998). OECD Thematic Review - The transition from initial education to working life: UK background report, Edinburgh Centre for Educational Sociology, University of Edinburgh.

Rainey, A. (2006). Loan debt could affect career choices, Chronicle of Higher Education, (April 14) 52(32), 24.

Richardson, M., Evans, C. \& Gbadamosi, G. (2009). Funding full-time study through part-time work. Journal of Education and Work, 22(4), 319-334.

Salamonson, Y. \& Andrew, S. (2006). Academic performance in nursing students: influence of part-time employment, age and ethnicity. Issues and Innovations in Nursing Education, $55(3), 342-351$.

Sibson, R. (2011). Career choice perceptions of undergraduate event, sport and recreation management students: An Australian case study. Journal of Hospitality, Leisure, Sport and Tourism Education, 10(2), 50-60.

Singaravelu, H.D., White, L.J. \& Bringaze, T.B. (2005). Factors influencing international student career choice: a comparative study. Journal of Career Development, 32(1), 46-59.

Smith, K., Clegg, S., Lawrence, E. \& Todd, M.J. (2007). The challenges of reflection: students learning from work placements. Innovations in Education and Teaching International, 44(2), 131-141.

Targetjobs (2008). Balancing study and part-time work [online]. http://targetjobs.co.uk/workexperience/articleview-36a_61.aspx (accessed July 17, 2008).

UCAS (2011). Balancing work and study, available at website, http:www.ucas.com/students/startinguni/managing_money_balancing_work_and_stu, accessed 19/7/2011

Watts, C. (2002). The effects of term-time employment on academic performance. Education + Training, 44(2), 67-75. 
Watts, C. \& Pickering, A. (2000). Pay as you learn: student employment and academic progress. Education + Training, 42(3), 129-134.

Webber, G. \& Williams, C. (2008). Part time work and gender division of labor. Qual Sociol, $31,15-36$.

Wignall, A. (2007). Earn while you learn and reap extra benefits. The Guardian, February 27, Education section.

Woolmer, B. \& Hill, D. (1990). Earn while you learn and reap extra benefits. Youth Studies 9, no.3: $30-36$

Yum, J.C.K., Kember, D. \& Siaw, I. (2005). Coping mechanism of part-time students. International Journal of Lifelong Education, 24(4), 303-317. 


\section{Appendix A - The Interview Questions}

\section{Introduction}

- What PT work do you currently undertake and how long have you worked there?

- How many hours per week do you work and has this changed over your degree studies?

- Have you held any previous PT jobs?

\section{A - The Job}

1. What motivates you to work part-time while studying for a degree?

2. What do you enjoy and dislike about your work?

3. Have you been promoted whilst at work? (Why pursue this promotion)?

4. Have you changed jobs (and why)?

5. What scope is there for progression in your current part-time job?

6. Do you feel committed to your employer?

7. If sacked tomorrow, how would you feel?

8. Do you undertake training? If so, how useful is this (transferability)?

9. Do you try to excel in the post?

\section{C - Education}

1. In what ways does work benefit or conflict with your studies?

2. If you were asked by your employer to work overtime, but this clashed with a seminar, what would you choose (and why)?

3. Does working reduce your private study/reading time?

\section{D - Career}

1. Have you made a career choice yet?

2. How is your career decision influenced by your part-time working, or vice versa?

3. Does your employer have a career path that is of interest to you?

4. Has your employer approached you about career development within the organization? What value is this job adding to your CV/Career?

\section{Closing}

- Any further points you would like to add? 